\title{
Assessment on Sustainability Report Assurances by Indonesian Companies for the Period in 2006-2018
}

\author{
Felisia $^{1}$, Sylvia Fettry Elvira Maratno ${ }^{2}$, Paulina Permatasari ${ }^{3}$ \\ \{felisia.liu@unpar.ac.id ${ }^{1}$, sylvia.fettry@unpar.ac.id ${ }^{2}$, paulina@ unpar.ac.id ${ }^{3}$ \} \\ Parahyangan Catholic University, Bandung, Indonesia ${ }^{1}$, Parahyangan Catholic University, Bandung, \\ Indonesia ${ }^{2}$, Parahyangan Catholic University, Bandung, Indonesia ${ }^{3}$
}

\begin{abstract}
Sustainability reporting has been requested by many parties, they also wish for credible information, which requires independent assurance. Assurance frameworks and standards play an important part in improving companies' reports towards being more credible. Assurance frameworks and standards also give directions that can be applied along with the assurance process. This study assesses the third-party assurance practices in Indonesian companies' sustainability reports from the year of 2006-2018. The result shows that sustainability assurance is still not a priority for most Indonesian companies.
\end{abstract}

Keywords Sustainability reports, Sustainability assurance

\section{Introduction}

Corporations need to communicate their commitment on sustainability issues. Therefore, sustainability reporting has become more important [1]. Recently, sustainability reporting has been requested by many parties, they also wish for credible information, which requires independent assurance. This increased demand for sustainability reporting and credible information requires independent assurance [2]. Assurance is a process that evaluate quality of organization's underlying systems, processes and competencies by using specific principles and standards [3]. Investors and analysts in making recommendations integrate information about sustainability. In order to improve credibility, companies also seek assurance on their sustainability reports [4].

Independent assurance of sustainability information is needed to improve reliability, validity and trustworthiness of disclosed information. Users trust more on high quality information, and of course high-quality information is also useful for organizations [5]. Assurance frameworks and standards play an important part in improving the credibility of companies' reports thus providing guidance for assurance process [4].

This study will analyze the sustainability assurance practices in Indonesia by several industry sectors, from the year of 2006-2018. We will assess the assurance statement presented in Indonesian companies' sustainability reports, to obtain an overview of sustainability assurance practice in Indonesia. We will also compare the assurance practice between each industry in Indonesia. 


\section{Literature Review}

\subsection{Sustainability Reporting and Sustainability Reports}

Sustainability Reporting is optional activity. It has two general purposes, the first one is to assess the current economic, environmental and social condition of companies, second is to informed stakeholders about a companies' efforts and sustainability progress [6].

The sustainability information disclosed by many firms only to accomplish the reporting purpose according to annual routine reporting [7]. Current reporting practice in sustainability is optional so that companies are opted in trying various experimentation with information disclosed [8].

Organizations can be helped to measure, understand and communicate their performance in economic, environmental, social and governance by sustainability reporting. A sustainability report is a report issued by a company or organization about how their daily activities may influence the economic, environmental and social conditions. It also presents companies' values and governance model, demonstrates its dedication to a sustainable global economy. Sustainability reporting process helps companies to consider their influence on sustainability issues and allows them to be transparent about the possibilities they're having [9].

Sustainability reports and sustainability reporting have different meanings. Sustainability reports are the published type of disclosure that are either stand-alone or incorporated into the financial report, while sustainability reporting is when companies disclose sustainability information, through various forms of media including sustainability reports. As readers should have understood by now, the focus of this study is on sustainability reports, i.e. the published reports where companies disclose their sustainability information. Due to this close distinction between the two, we remind the readers that when we say sustainability reporting, sustainability reports or even CSR reports, we are talking about the published reports, and not the general definition of sustainability reporting [10].

\subsection{Assurance on Sustainability Reporting}

Some stakeholders have demanded for transparency, they also questioned the integrity of the information that is published by firms especially about sustainability reports, [12], [13]. To answer it, some firms started to voluntarily give external independent assurance in their sustainability reports. This is done in order to improve credibility and reliability of the reports. O’Dwyer and Owen stated [14], in 1997-1998 external independent assurance of sustainability reports has begun to show.

Lots of organizations have encouraged the practice of independent assurance for sustainability. It is to enhance credibility and the quality of sustainability reports. For example, GRI [5] convinces the independent assurance of sustainability reports as a tool to increase sustainability reports' quality and credibility.

In Fortune Global 250 survey, KPMG [15] stated that increased quality of reported information, increased credibility among stakeholders and increased reporting processes are the main keys for finding assurance of a sustainability report. Assurance process increases sustainability report credibility. Hodge et al. [16] studied 145 students enrolled in MBA programs at two large Australian universities, the study found out that provision of an assurance statement with a sustainability report generates higher credibility reports than when no assurance is delivered. In addition, they also stated report users place more trust in sustainability reports when assurance is delivered by top tier accountancy firms against to specialist consultants. 
Owen et al. [17] interviewed senior corporate responsibility managers from ten FTSE100 organizations, and representatives of three key stakeholder groups (investor, NGO and the trade union movement). They stated that while there is some proof that stakeholders are interested in assurance, especially on the part of NGO, it is the internal of an organization that drives the assurance.

Assurance of sustainability reports is a rather new implementation and not regulated in most of countries, there are different types of organizations providing assurance services using different scopes, methodologies, and assurance statements [12], [14], [15], [17], [18], [19], [20], [21], [22].

The two most famous frameworks for assurance services are the AA1000 Assurance Standard (AA1000AS) launched in March 2003 by Accountability [23], and the International Audit Assurance Standards Boards (IAASB)'s International Standard on Assurance Engagements (ISAE 3000). There are also arguments that stated assurance based on the combined use of AA1000AS and ISAE 3000 is likely to give improved results [24].

The International Audit Assurance Standards Board [23, p. 19] defines an assurance engagement as "an engagement in which a practitioner aims to obtain sufficient appropriate evidence in order to express a conclusion designed to enhance the degree of confidence of the intended users other than the responsible party about the outcome of the measurement or evaluation of an underlying subject matter against criteria". It also differentiates two types of assurance engagement which are reasonable assurance engagements and limited assurance engagements.

ISAE 3000's define assurance engagement has a more technical explanation. AA1000AS used more common language to define it as "an engagement in which an assurance provider evaluates and expresses a conclusion on an organization's public disclosure about its performance as well as underlying systems, data and processes against suitable criteria and standards in order to increase the credibility of the information for the intended audience" [25, p. 23].

\subsection{Sustainability Reporting Assurance Guideline}

This section will discuss the sustainability reporting standards that are used by sustainability assurance practitioners in conducting their assurance engagement on companies' sustainability reports. According to the CPA journal [4], in the US "ISAE 3000 seems to be more popular among audit firms (Deloitte, $61.54 \%$ of engagements used ISAE 3000; EY, 50\%; KPMG, $69.23 \%$; PWC, $47.83 \%$ while specialist assurance providers/technical experts seem to favor AA1000AS (76.47\%, vs. $11.76 \%$ for ISAE 3000$)$ ". The standards that will be discussed here are those that are more common and mostly used in Indonesian companies' assurance reports, which is similar with the US, namely AA1000AS and ISAE300.

\subsubsection{AA1000 AS}

The AA1000 AS [25] is accepted globally and available standard that provides the requirements for managing sustainability assurance. Sustainability assurance in accordance with the AA1000 AS [25] examines and gives opinions on the essence and scope of adherence to the AA1000 AccountAbility Principles, and where applicable the quality of information on sustainability performance that has been disclosed in public. This standard is principally intended for use by sustainability assurance practitioners and providers. This standard may also be functional to report preparers looking for assurance in accordance with this standard, and to users of sustainability assurance reports and statements and other standards developers [25, p. $8]$. 
There are two types AA1000AS [25] sustainability assurance engagement which are type 1 - AccountAbility Principles and type 2 - AccountAbility Principles and Performance Information. Type 1 explained that the assurance contributor shall examine the essence and scope of the organization's adherence to all three AA1000 AccountAbility Principles. While type 2 explained that the assurance contributor shall evaluate the essence and scope of the organization's adherence to the AA1000 AccountAbility Principles, as for type 1. An assurance engagement may be implemented to give a high or a moderate level of assurance. Since different focus of attentions may be communicated in one assurance engagement, a high level of assurance may be provided for some focus while a moderate level of assurance may be provided for other focus in the same assurance report [25, pp. 9-10].

\subsubsection{ISAE3000}

The International Standard on Assurance Engagements (ISAE) 3000 is a common standard for any assurance engagement other than audits or reviews of historic financial information. The International Auditing and Assurance Standards Board (IAASB) of the International Federation of Accountants (IFAC) 25 developed the standard, and it was published in 2003. Its stress is on overall procedures for proof collecting processes and assurer independence. An assurance report 'in accordance with ISAE 3000' can only be published by professional accountants, as the assurance contributor must also comply with the IESBA Code of Ethics for Professional Accountants. Other assurance contributors may use assurance approaches based on ISAE 3000 or which merge components of ISAE 3000 with other standards, such as AA1000AS [5, p. 12].

This International Standard on Assurance Engagements (ISAE) is aimed to establish basic principles and important procedures for, and to give direction to, professional accountants in public practice (for purposes of this ISAE referred to as "practitioners") for the performance of assurance engagements other than audits or reviews of past financial information enclosed by International Standards on Auditing (ISAs) or International Standards on Review Engagements (ISREs) [26, p. 293].

This ISAE uses the phrases "reasonable assurance engagement" and "limited assurance engagement" to differentiate between the two types of assurance engagement a practitioner is permitted to do. The goal of a reasonable assurance engagement is a curtailment in assurance engagement risk to an acceptably low level in the conditions of the engagement as the basis for a positive form of expression of the practitioner's conclusions. The goal of a limited assurance engagement is a curtailment in assurance engagement risk to a level that is acceptable in the situations of the engagement, but where that risk is higher than for a reasonable assurance engagement, as the basis for a negative form of expression of the practitioner's conclusion [26, p. 293].

\section{Research Method}

Within this research, content analysis and literature review were used. Content analysis is a technique in research for creating reliable and valid conclusions from texts or other meaningful focus to the factors of their use [27]. The method of content analysis in this research was carried out by reading from certain sources in accordance with the research objectives to help analyze the assurance statement assessment based on the sustainability reposting assurance statement disclosure in Indonesia's company from various industries. 
While literature review is a study that helps researchers to think or understand more deeply about a problem. This literature review can be done by reading and studying books, journals, newspapers, magazine, documents and so on that are relevant to research. This literature review can help researchers to understand more deeply about the knowledge that has been studied and help to develop a problem statement with accuracy and clarity [28].

The research object used in this research is the sustainability report published by companies in Indonesia from various industries period 2006 to 2018 with a total of 144 companies and 766 sustainability reports. We assessed the sustainability reports and checked whether it have used third-party assurance service and have included the assurance statement in their reports. If the report presents an assurance statement, we conducted an assessment on its assurance statement to evaluate several aspects, namely the assuror, assurance standard used, and assurance type.

\section{$4 \quad$ Analysis \& Findings}

\subsection{Analysis of Assurance Statement on Indonesian Companies' Sustainability Reports in 2006-2018 \\ Based on this research, it shows that during 2006 to 2018, of the 144 companies in Indonesia which are included in several industries, most companies in Indonesia have published sustainability reports with assurance statements. There are 114 assurance reports that have been published in the period of 2006-2018.}

\subsubsection{Construction Industry}

Table 1. Assurance Statement of Construction Industry

\begin{tabular}{|c|c|c|c|c|c|c|c|c|}
\hline \multirow{2}{*}{$\begin{array}{l}\text { No } \\
\text { of } \\
\text { SR }\end{array}$} & \multirow{2}{*}{$\begin{array}{c}\text { No of } \\
\text { Assurance }\end{array}$} & \multicolumn{2}{|c|}{ Assured By } & \multicolumn{3}{|c|}{ Assurance Standard } & \multicolumn{2}{|c|}{ Assurance Type } \\
\hline & & $\begin{array}{l}\text { Accounting } \\
\text { Firm }\end{array}$ & Others & AA1000 & ISAE300 & Other & Reasonable & Limited \\
\hline 54 & 4 & 0 & 4 & 4 & 0 & 0 & 0 & 4 \\
\hline
\end{tabular}

In this industry, there are 12 companies that are the object of research. There were 54 sustainability reports issued in the period from 2006 to 2018, but only 4 sustainability reports were assured. All 4 reports were assured by other non-accounting firms, namely SR Asia and BSI Indonesia, which adopted the AA1000 standard with a limited (moderate) level of audit.

\subsubsection{Food Industry}

Table 2. Assurance Statement of Food Industry

\begin{tabular}{ccccccccc}
\hline No & No of & \multicolumn{2}{c}{ Assured By } & \multicolumn{2}{c}{ Assurance Standard } & \multicolumn{2}{c}{ Assurance Type } \\
\cline { 2 - 7 } of & $\begin{array}{c}\text { No } \\
\text { SR }\end{array}$ & $\begin{array}{c}\text { Assurance } \\
\text { Accounting } \\
\text { Firm }\end{array}$ & Others & AA1000 & ISAE300 & Other & Reasonable & Limited \\
\hline 17 & 1 & 1 & 0 & 0 & 0 & 1 & 1 & 0 \\
\hline
\end{tabular}


In this industry, there are 3 companies that are the object of research. There were 17 sustainability reports that were issued in the period of 2006 to 2018, but only 1 sustainability report was assured. The assuror who conducted the assurance is an accounting firm, namely Deloitte, which adopted another standard, namely Standard 3810N with a reasonable (high) level of audit.

\subsubsection{Oil and Gas Industry}

Table 3. Assurance Statement of Oil and Gas Industry

\begin{tabular}{ccccccccc}
\hline No & \multirow{2}{*}{$\begin{array}{c}\text { No of } \\
\text { of }\end{array}$} & \multicolumn{2}{c}{ Assured By } & \multicolumn{2}{c}{ Assurance Standard } & \multicolumn{2}{c}{ Assurance Type } \\
\cline { 2 - 8 } SR & Assurance & $\begin{array}{c}\text { Accounting } \\
\text { Firm }\end{array}$ & Others & AA1000 & ISAE300 & Other & Reasonable & Limited \\
\hline 61 & 14 & 2 & 12 & 11 & 7 & 3 & 1 & 13 \\
\hline
\end{tabular}

In this industry, there are 14 companies that are the object of research. There were 61 sustainability reports that were issued in the period of 2006 to 2018, but only 14 sustainability reports were assured. The assurors who conducted the assurance are 2 accounting firms, namely PwC and Deloitte and 12 other non-accounting firm such as Moores Rowland, SGS Indonesia and SR Asia which adopted the AA1000, ISAE3000, and other standards, namely GRI Standards, IPIECA / API / IOGP and Oil and gas industry direction on voluntary sustainability reporting (2015). Audit assurance is carried out with 2 types of audits, including 1 having a reasonable (high) type and 13 others having a limited (moderate) type.

It should be noted that there are more than 1 standard used in the assurance processes, so that the number of assurance standards and the number of assurance statements issued are not the same.

\subsubsection{Mining Industry}

Table 4. Assurance Statement of Mining Industry

\begin{tabular}{|c|c|c|c|c|c|c|c|c|}
\hline \multirow{2}{*}{$\begin{array}{c}\text { No } \\
\text { of } \\
\text { SR }\end{array}$} & \multirow[b]{2}{*}{$\begin{array}{c}\text { No of } \\
\text { Assurance }\end{array}$} & \multicolumn{2}{|c|}{ Assured By } & \multicolumn{3}{|c|}{ Assurance Standard } & \multicolumn{2}{|c|}{ Assurance Type } \\
\hline & & $\begin{array}{l}\text { Accounting } \\
\text { Firm }\end{array}$ & Others & AA1000 & ISAE300 & Other & Reasonable & Limited \\
\hline & 136 & 35 & 2 & 33 & 20 & 21 & 19 & 30 \\
\hline
\end{tabular}

In this industry, there are 19 companies that are the object of research. There were 136 sustainability reports issued in the period from 2006 to 2018, but only 35 sustainability reports were assured. The assuror who conducted assurance are 2 accounting firms, namely KPMG and ERNST \& YOUNG, and 33 other non-accounting firms, such as Moores Rowland, SGS Indonesia, LQRA, and SR Asia which adopted the AA1000 standard, ISAE3000, and other standards such as GRI, Mining Sector Supplement, Rule NPO1 (Brazilian Institute of Accountants), Rule NBC TO 3000 (Brazilian Federal Accounting Council), ICMM Assurance Procedure, POJK 51, Mining and Metals Sector Disclosure, and there is one standard that is not identified. Audit assurance is carried out with 2 types of audits, including 5 (five) having a reasonable (high) type and 30 others having a limited (moderate) type. 
Should be noted that the sustainability reports were assured using more than 1 standard, so that the number of assurance standards and the number of assurance statements issued were not the same.

\subsubsection{Electric Industry}

Table 5. Assurance Statement of Electric Industry

\begin{tabular}{|c|c|c|c|c|c|c|c|}
\hline \multirow{3}{*}{$\begin{array}{c}\text { No } \\
\text { of } \\
\text { SR } \\
36\end{array}$} & \multirow{2}{*}{$\begin{array}{c}\text { No of } \\
\text { Assurance }\end{array}$} & \multicolumn{2}{|c|}{ Assured By } & \multicolumn{3}{|c|}{ Assurance Standard } & Assurance Type \\
\hline & & $\begin{array}{l}\text { Accounting } \\
\text { Firm }\end{array}$ & Others & AA1000 & ISAE300 & Other & Reasonable Limited \\
\hline & 0 & 0 & 0 & 0 & 0 & & 0 \\
\hline
\end{tabular}

In this industry, there are 5 companies that are the object of research. There were 36 sustainability reports issued in the period from 2006 to 2018, but no sustainability reports were assured.

\subsubsection{Airport Industry}

Table 6. Assurance Statement of Airport Industry

\begin{tabular}{ccccccccc}
\hline No & \multirow{2}{*}{$\begin{array}{c}\text { No of } \\
\text { of }\end{array}$} & \multicolumn{2}{c}{ Assured By } & \multicolumn{2}{c}{ Assurance Standard } & \multicolumn{2}{c}{ Assurance Type } \\
\cline { 2 - 8 } & Assurance & $\begin{array}{c}\text { Accounting } \\
\text { Firm }\end{array}$ & Others & AA1000 & ISAE300 & Other & Reasonable & Limited \\
\hline 15 & 0 & 0 & 0 & 0 & 0 & 0 & 0 & 0 \\
\hline
\end{tabular}

In this industry, there are 4 companies that are the object of research. There were 15 sustainability reports issued in the period from 2006 to 2018, but no sustainability reports were assured.

\subsubsection{Other Industry}

Table 7. Assurance Statement of Other Industry

\begin{tabular}{|c|c|c|c|c|c|c|c|c|}
\hline \multirow{2}{*}{$\begin{array}{l}\text { No } \\
\text { of } \\
\text { SR }\end{array}$} & \multirow[b]{2}{*}{$\begin{array}{c}\text { No of } \\
\text { Assurance }\end{array}$} & \multicolumn{2}{|c|}{ Assured By } & \multicolumn{3}{|c|}{ Assurance Standard } & \multicolumn{2}{|c|}{ Assurance Type } \\
\hline & & $\begin{array}{l}\text { Accounting } \\
\text { Firm }\end{array}$ & Others & AA1000 & ISAE300 & Other & Reasonable & Limited \\
\hline 304 & 45 & 0 & 45 & 35 & 9 & 21 & 5 & 40 \\
\hline
\end{tabular}

In this industry, there are 55 companies that are the objects of research. There were 304 sustainability reports issued in the period from 2006 to 2018, but only 45 sustainability reports were assured. The assurors who carried out the assurance are other non-accounting such as Det Norske Veritas AS, Moores Rowland, SGS Indonesia, NCSR and SR Asia who adopted the AA1000, ISAE3000, and other standards such as GRI standard, the DNV Protocol for Verification of Sustainability Reporting and there is one standard that is not identified. Audit assurance is carried out with 2 types of audits, including 5 having a reasonable (high) type and 40 others having a limited (moderate) type. 
Should be noted that several sustainability reports were assured using more than 1 standard, so that the number of assurance standards and the number of assurance statements issued were not the same.

\subsubsection{Financial Industry}

Table 8. Assurance Statement of Financial Industry

\begin{tabular}{|c|c|c|c|c|c|c|c|c|}
\hline \multirow{2}{*}{$\begin{array}{c}\text { No } \\
\text { of } \\
\text { SR }\end{array}$} & \multirow[b]{2}{*}{$\begin{array}{c}\text { No of } \\
\text { Assurance }\end{array}$} & \multicolumn{2}{|c|}{ Assured By } & \multicolumn{3}{|c|}{ Assurance Standard } & \multicolumn{2}{|c|}{ Assurance Type } \\
\hline & & $\begin{array}{l}\text { Accounting } \\
\text { Firm }\end{array}$ & Others & AA1000 & ISAE300 & Other & Reasonable & Limited \\
\hline 143 & 15 & 0 & 15 & 15 & 8 & 13 & 0 & 15 \\
\hline
\end{tabular}

In this industry, there are 32 companies that are the object of research. There were 143 sustainability reports issued in the period from 2006 to 2018, but only 15 sustainability reports were assured. The assurors who carried out the assurance are other non-accounting firms, such as Moores Rowland and SR Asia which adopted the AA1000, ISAE3000, and other standards such as GRI standard and POJK 51. All of the assurance was carried out with the same assurance type, namely limited (moderate).

It should be noted that there are more than 1 standard used in the assurance processes, so that the number of assurance standards and the number of assurance statements issued are not the same.

\subsection{Comparison of Assurance Practices on Indonesian Companies' Sustainability Reports in 2006-2018 \\ Based on the data of third-party assurance practices on sustainability reports by the Indonesian companies for the period of 2006-2018, Table 9 below presents the comparison of the assurance practice by each industry.}

Table 9. Comparison of Assurance Practices by Industry

\begin{tabular}{lcccc}
\hline Industry & $\begin{array}{c}\text { Number of } \\
\text { Companies }\end{array}$ & $\begin{array}{c}\text { Number of } \\
\text { Sustainabili } \\
\text { ty Reports }\end{array}$ & $\begin{array}{c}\text { Number of } \\
\text { Assurances }\end{array}$ & $\begin{array}{c}\text { SR to } \\
\text { Assurance } \\
\text { Ratio }\end{array}$ \\
\hline Construction & 12 & 54 & 4 & $7.41 \%$ \\
Food & 3 & 17 & 1 & $5.88 \%$ \\
Oil and Gas & 14 & 61 & 14 & $22.95 \%$ \\
Mining & 19 & 136 & 35 & $25.74 \%$ \\
Electric & 5 & 36 & 0 & $0 \%$ \\
Airport & 4 & 15 & 0 & $0 \%$ \\
Other & 55 & 304 & 45 & $14.80 \%$ \\
Financial & 32 & 143 & 15 & $10.49 \%$ \\
\hline \multicolumn{1}{c}{ Total } & $\mathbf{1 4 4}$ & $\mathbf{7 6 6}$ & $\mathbf{1 1 4}$ & $\mathbf{1 4 . 8 8 \%}$ \\
\hline \multicolumn{1}{r}{} & & & &
\end{tabular}


From Table 9 above, it can be seen that the mining industry as well as oil and gas industry are the industries with the highest ratio of assurance practice, with the mining industry's ratio reached $25.74 \%$ while the oil and gas industry's ratio is $22.95 \%$. On the other hand, electric industry and airport industry have the lowest assurance ratio, with both industries have $0 \%$ ratios, which means that none of the electric and airport industry companies have used thirdparty assurance services for their sustainability reports.

This finding can be said to be appropriate with several previous studies that stated that mining, oil, gas and chemicals companies provide more significantly corporate responsibility disclosures and are probable to have their sustainability reports assured than other industries [29], [30], [31]. Companies in the industries that are perceived as more dangerous or present a prospective harm for the environment will produce higher quality reports and publish their reports with assurance statements [32].

For the electric and airport industries, the number of companies in those industries are still quite few, with only 5 and 4 companies respectively. Electric and airport sector can also be considered as not harmful to the environment, so that sustainability reporting disclosure and its assurance have not become priority for those companies.

\section{Conclusion}

Based on the data analysis conducted in this study, it can be concluded that the sustainability assurance practice is still rarely applied in Indonesia. Even in several industries, the sustainability reporting practice is still inconsistent, where some companies did not publish their sustainability report annually or stop publishing their reports after several years. For firms in the industries that present a prospective harm for the environment, their sustainability report to assurance ratio can be considered quite low, with mining and oil and gas industries' ratio still below $30 \%$. It can be said that sustainability assurance is still not a priority for Indonesian companies. Whereas third-party assurance on sustainability report is quite important certify the reliability and accuracy of information disclosed in the report, because it will affect decisionmaking processes of investors, stakeholders, and other parties.

\section{References}

[1] O. Boiral, I. Heras-Saizarbitoria and M.-C. Brotherton, "Assessing and Improving the Quality of Sustainability Reports: The Auditors' Perspective," Journal of Business Ethics, pp. 703-721, 2019.

[2] K. Heenetigala and A. F. Armstrong, "Credibility of sustainability reports of mining sector companies in Australia: An investigation of external assurance," in 19th International Scientific Conference on Economic and Social Development, Melbourne, Australia, 2017.

[3] S. Zadek and P. Raynard, "The Future of Sustainability Assurance," ACCA Research Report, 2004.

[4] S. Rao, "Current State of Assurance on Sustainability Reports," The CPA Journal, 2017.

[5] GRI, Global Reporting Initiatives Research and Development Series: The external assurance of sustainability reporting, Amsterdam, 2013.

[6] R. Lozano and D. Huisingh, "Inter-linking issues and dimensions in sustainability reporting," Journal of cleaner production, vol. 19, no. 2-3, pp. 99-107, 2011.

[7] K. A. K. Gnanaweera and N. Kunori, "Corporate sustainability reporting: Linkagege of corporate disclosure information and performance indicators," Cogent Business \& Management, pp. 1-21, 2018. 
[8] R. Hahn and M. Kühnen, "Determinants of sustainability reporting: A review of results, trends, and opportunities in an expanding field of research," Journal of Cleaner Production, pp. 1-53, 2013.

[9] N. S. Singhal and A. Dev, "Global Reporting Initiative, Sustainability Reporting," in Proceedings of the 6th International Conference on Operation and Technology of Offshore Support Vessels, Singapore, 2016.

[10] M. Danarp and A. Ramish, Sustainability reports - Legitimizing negative aspects (A qualitative study on the Swedish steel industry), Sweden: Umeå University, 2019.

[11] W. S. Laufer, "Social accountability and corporate greenwashing," Journal of Business Ethics 43(3), pp. 253-261, 2003.

[12] J. Moneva, P. Archel and C. Correa, "GRI and the camouflaging of corporate unsustainability," Accounting forum 30, pp. 121-137, 2006.

[13] C. A. Ramus and I. Montiel, "When are corporate environmental policies a form of greenwashing?," Business \& Society 44(4), pp. 377-414, 2005.

[14] B. O'Dwyer and D. L. Owen, "Assurance statement practice in environmental, social and sustainability reporting: A critical evaluation," The British Accounting Review 37(2), pp. 205-229, 2005.

[15] KPMG Global Sustainability Services, International survey of corporate responsibility reporting 2008, Amstelveen, 2008.

[16] K. Hodge, N. Subramaniam and J. Stewart, "Assurance of sustainability reports: Impact on report users' confidence and perceptions of information credibility," Australian Accounting Review, vol. 19, по. 3, pp. 178-194, 2009.

[17] D. Owen, W. Chapple and A. Urzola, Key issues in sustainability assurance, London: International Centre for Corporate Social Responsibility, 2009.

[18] C. M. Deegan, B. J. Cooper and M. Shelly, "An investigation of TBL report assurance statements: UK and European evidence.," Managerial Auditing Journal 21(4), pp. 329-371, 2006.

[19] Fede'ration des Experts Comptables Europe'ens, IAASB consultation paper on assurance aspects of G3-The global reporting initiative's 2006 draft sustainability reporting guidelines, Bruxelles, 2006.

[20] G. Frost and N. Martinov-Bennie, Sustainability reporting assurance: Market trends and information content, Victoria: CPA Australia Ltd, 2010.

[21] P. Perego, "Causes and consequences of choosing different assurance providers: An international study of sustainability reporting," International Journal of Management 26(3), pp. 412-425, 2009.

[22] S. Romero, S. Ruiz and B. Ferna'ndez-Feijo'o, "Assurance statement for sustainability reports: The case of Spain," in Proceedings of the Northeast Business \& Economics Association, San Diego, 2010.

[23] AccountAbility, AA 1000 stakeholder engagement standard 2011-Final exposure draft, London, 2011.

[24] KPMG Global Sustainability Services and AccountAbility, Assurance standards briefing-AA1000 assurance standard \& ISAE3000, Amsterdam, 2005.

[25] AccountAbility, AA1000 assurance standard 2008, London, 2008.

[26] IAASB, International Standard on Assurance Engagements (ISAE) 3000: Assurance Engagements Other than Audits or Reviews of Historical Financial Information, New York, 2005.

[27] K. Krippendorff, Content analysis: An Introduction to Its Methodology, California: Sage Publications, 1980.

[28] U. Sekaran and R. Bougie, Research Methods for Business: A Skill Building Approach 7th Edition, United Kingdom: John Wiley \& Sons Ltd., 2016. 
[29] F. Alali and S. Romero, "The use of internet for corporate reporting in the Mercosur - the Argentina case," working paper, 2009.

[30] R. Simnett, A. Vanstraelen and W. F. Chua, "Assurance on sustainability reports: an international comparison," The Accounting Review, vol. 84, no. 3, pp. 937-967, 2009.

[31] A. Kolk and P. Perego, "Determinants of the adoption of sustainability assurance statements: an international investigation," Business Strategy and the Environment, 2008.

[32] B. Fernández-Feijóo-Souto, S. Romero and S. Ruiz-Blanco, "Measuring quality of sustainability reports and assurance statements: characteristics of the high quality reporting companies," International Journal of Society Systems Science, vol. 4, no. 1, pp. 5-27, 2012. 